\title{
Teacher's Nonverbal Communication in Teaching Learning Process at SMP Negeri 2 Robatal Sampang Madura
}

\author{
Wildona Zumam
}

\begin{abstract}
Mahfud
Abstract

The teacher is not only used verbal communication but also used nonverbal communication, this study aims to investigate the teacher use nonverbal communication in teaching learning process and the teachers' nonverbal communication effect on the classroom atmosphere at SMP Negeri 2 Robatal Sampang Madura. The subject of the study is the teacher and the students. The instruments used to get the data were observation, interview and documentation. Observation was applied in order to know the use nonverbal communication in teaching learning process at SMP Negeri 2 Robatal Sampang and activity in the classroom. Interviews were conducted to know the effect of nonverbal communication in teaching learning process at SMP Negeri 2 Robatal Sampang. The result of the shows that teachers' nonverbal used in teaching learning process are hands, space and distance, touching and chronemics. Hands is nonverbal the most used by the teacher in teaching learning process, the manner of the used hands in teaching learning process, he ups his hands to ask students to come forward. Space and distance is the second nonverbal that's more often than touching in teaching learning process after hands. It used the teacher to explain his material in the used space and distance the teacher stands up in front of a students to explains his material, touching is nonverbal used the teacher in teaching learning process, touching used the teacher to communication with a student's while the teacher asks a students to come forward if the students didn't want to come forward the teacher stand up beside a students and be touches their body. Chronemics was rarely used by the teacher in the classroom, chonemics used the teacher while he gives task to the students he gives limed the time to the students to prepare the material that would be presentation. Beside that the effect of nonverbal communication used were helping students understanding and accompanying to verbal message. Helping students understanding more easily to a students to receive the material that's explains by the teacher. Accompanying to verbal message is a student's more easily understand to get the point of teachers' explanation in teaching learning process.
\end{abstract}

Key words: communication, nonverbal

\section{INTRODUCTION}

The teacher is essential to get the success of learning process. The teacher gives knowledge to their students. Without teachers learning will be difficult to do. The teacher carry out education through the activities of learning with teach students. The teacher has many obligations in learning of lesson plan, carry out the learning process and do evaluation of learning has done. The teacher trains students 
and they make a student's smart and giving knowledge to students. The teacher not only as instructor that gives knowledge but also as educator that gives a briefing to students in teaching learning process.

The teachers give teaching learning process and they need strategies and method to get the success, because teaching learning is designed and implemented as a system, in the formation of professional competence and requires functional integration of theory and practice as well as the materials and methodology their convey. Formation of professional competence requires field experience gradually starting from the experience, training and skills up to the implementation of the teaching and learning process in the classroom.

In teaching the teacher will try as much as possible by using their skills and capabilities so that students can understand the explanation given by the teachers. The teachers should be able to carry out and know the things that are technical during in learning process takes place in the classroom interaction in the learning process. During the learning process the teacher has a duty to giving knowledge attitudes and skills to students and has a responsibility to see everything that happens in the classroom to assist in the development of students. Therefore, the capability of effective in communication both verbal and nonverbal communication is important.

Nonverbal communication includes sounds, gestures, body movements, eye contacts, facial expressions, pitch or tone of a voice, spatial distance, apparent behavior, postures, and dress of an individual. Nonverbal communication helps teachers to have understood in sending and recent message produce in verbal communication. According to Meghdari (2016:3). Nonverbal communication has different forms, when peoples are speaking people also unconsciously use their hands, lips, head movement, body postures and eyes to explain our purpose clearer to bring messages in communication.

Nonverbal communication consists of messages other than words that are used in our interactions with others. Such messages are typically sent intent and interpreted by receivers as meaningful. The writer underscores how tone of voice, facial expressions, 
and body language play roles in such communication.

The important of nonverbal communication is the teacher to support and equip verbal communication to get the message that conveyed by the teachers. It can be more easily made in impression in the minds of students to invite their students to join the class. The teachers at SMP Negeri 2 Robatal Sampang used their finger, hand, eye contact and their body in teaching. When the teachers explained the material to their students sometimes the teachers scratched their head, pointed to the students used finger, and only silent sit in front of class to do not something. There is no synchronous between verbal and nonverbal teachers in teaching learning process that will influence students. The teachers at SMP Negeri 2 Robatal Sampang used non interactions situation when the teachers give teaching to their students in teaching learning process. Therefore, the researcher wants to do research to teachers of SMP Negeri 2 Robatal Sampang especially English Teachers.

Based on the explanation above, the researcher can take under title of this research “Teacher's Nonverbal communication in Teaching Learning
Process at SMP Negeri 2 Robatal Sampang" and there are two research problems should be taken into consideration:

1. How does the teacher use non verbal communication in teaching learning process at SMP Negeri 2 Robatal Sampang?

2. How does the teachers' nonverbal communication effect on the classroom atmosphere at SMP Negeri 2 Robatal Sampang?

The result of the study is expected to significance the teacher and the researcher to know nonverbal communication.

1. For the students

To understand the teachers' movements when they are explain their material, to give motivation to the students to learn more nonverbal communication.

2. For the teachers

Increase the teachers' nonverbal communication in teaching learning process and to train sensitivity the teacher to change their students in the classroom or in teaching learning process. 
3. For linguistics

It will be more useful for linguistics

to more understanding about gesture especially kinds of gesture.

4. For the researcher

This research expected develops the knowledge of the researcher in communication especially in nonverbal communication.

This research is qualitative research by using descriptive approach. According to Merriam in Yin, (2008:18) a case study is an empirical inquiry that investigates a contemporary phenomenon and contexts are not clearly evident. The case study can be further defined by its special features. In this research, the researchers want to describe some of the data of the teacher's nonverbal communication in teaching learning process especially English teachers at SMP Negeri 2 Robatal Sampang.

The subjects of the research are the teachers and students of SMP Negeri 2 Robatal Sampang especially
English Teachers. There are two English teachers at SMP Negeri 2 Robatal Sampang. And the researcher only used observation, interview, documentation to get accurate the data of teachers and students at SMP Negeri 2 Robatal Sampang.

\section{FINDINGS AND DISCUSSION}

\section{FINDINGS}

The teachers Nonverbal Communication in Teaching Learning Process at SMP Negeri 2 Robatal 2 Sampang.

Based on the results of observation at SMP Negeri 2 Robatal Sampang, The rseachers find nonverbal used the teacher in teaching learning process. The used hands,space \& distance, touching in teaching process, it is presented in table 1. 
Table 1. The Teachers Nonverbal Communication in Teaching Learning Process at SMP Negeri 2 Robatal Sampang.

\begin{tabular}{|l|l|l|l|}
\hline No & Nonverbal & Frequency & Percent \\
\hline 1 & Hands & 62 & $62 \%$ \\
\hline 2 & Space and Distance & 34 & $34 \%$ \\
\hline 3 & Touching & 2 & $2 \%$ \\
\hline 4 & Chronemics & 2 & $2 \%$ \\
\hline
\end{tabular}

Based on the table 1. Hands, space and distance, touching, chronemics are nonverbal communication used by the teacher at SMP Negeri 2 Robatal Sampang. Hands is nonverbal the most used by the teacher in teaching learning process, the used of hands in teaching learning process he up his hands to asks a students to come forward. Space and distance is nonverbal that's more often than touching in teaching learning process after hands when the teacher explains his material he stands up in front of a students. Touching is nonverbal used the teacher in teaching learning process used the teacher to communication with a student's while the teacher asks a students to come forward if the students didn't want to come forward, the teacher stand up beside a students and he touches his body. Chronemics was rarely used the teacher while he gives task to the students he gives limed the time to the students to prepare the material that would be presentation. Whereas, paralanguage is nonverbal didn't used the teacher in teaching learning process.

The Teachers' Nonverbal Communication Effect on the Classroom Athmosphere at SMP Negeri 2 Robatal Sampang.

Table 2. Explain the effects of nonverbal communication used the teacher at SMP Negeri 2 Robatal sampan by using structure interview, the researcher gave some questions to the teacher and students at SMP Negeri 2 Robatal Sampang to get the data about the effect of nonverbal communication on the classroom atmosphere. 
Table 2. The teachers' nonverbal communication effect on the classroom athmosphere at SMP Negeri 2 Robatal Sampang.

\begin{tabular}{|l|l|l|l|}
\hline No & Effect Nonverbal & Frequency & Percent \\
\hline 1 & Helping Students Understanding & $16 \%$ & $50 \%$ \\
\hline 2 & $\begin{array}{l}\text { Accompanying to Verbal } \\
\text { Message }\end{array}$ & $16 \%$ & $50 \%$ \\
\hline
\end{tabular}

To the teacher explain are the effect of nonverbal communication used by the teacher at SMP Negeri 2 Robatal Sampang. All of the students give the same opinion about the effect of nonverbal communication used by the teacher at SMP Negeri 2 Robatal Sampang. All of the students give the same opinion about the effect of nonverbal communication used by the teacher at SMP Negeri 2 Robatal Sampang. It's effect helping students understanding and accompanying to verbal message.

\section{DISCUSSION}

The Teacher Nonverbal Communication in Teaching Learning Process at SMP Negeri 2 Robatal Sampang.

While the teaching learning process at SMP Negeri 2 Robatal sampan of Nonverbal communication used the teacher they are hands, space and distance, touching and chronemics.

\section{a. Hands}

In the first meeting the researcher did observation at SMP Negeri 2 Robata Sampang when the teacher in the classroom, he was giving the tasks paper to the students to write his answer on the blackboard the teacher call one of students again to write his answer on the blackboard the first students written his answer on the left and the second students written his answer on the right board after they finished their answer, the teacher used hands in explain the material about comparative degree, he was using his hands both left and right to choose one of correct answer, he gave suggestion to the students by up their hands to left and right to determine the students choose the right answer. To others example in 
the first meeting used hands will explain.

The teacher ask to the students to written answer number five, after the students finishes his answer, the teacher asks one of the students to translate from English into Indonesia because the students did not translate and his translate it is not correct the teacher give explanation to the students thought the students did not study last night, after that the teacher asks to all of the student about their answer from number five. Then, he gave question to the students, he said " what is number now?" and he was using his hands both left and right to show number six by using his hands with the manner, he opened all of the finger right hands and closes four finger of the left hands.

In the second meeting the researcher did observation at SMP Negeri 2 Robatal Sampang. When the teacher in the classroom, he divides a student into some group, after the teacher was divided to be some group, the teacher moves to back chair. Then, the teacher call the next group to presentation the group come forward to presentation their product, that consisting of three students, one student is presenting their product and others for sale to their friends, one of students come to the teacher and tray to sale for him because the teacher doesn't want to buy students' product, so that the teacher up his hands and show palm of hand to students to reject the product.

For the next perform the teacher called the seventh groups to presentation their products, when the students were presenting, the teacher asks to the side students the name of students that's sitting in front of the teacher, after that the seventh group finished their presenting, the teacher called the last group that would presentation, when the students was come forward the teacher used his hands both left or right to give expostulation to the students, that groups is the last group that will presentation, the teacher used hand with the manner he ups the left hands and the palm of right hands putted on the left hands .

In the third meeting the researcher did observation at SMP Negeri 2 Robata Sampang. When 
the teacher in the classroom, he was sitting down in his chair because there are no students to presentation. The teacher gives offering to a student to presentation their products because there is not a student's that brave to come forward, the teacher used his hands ask students to try presentation their products with the manner he ups his hands to side, that presented.

\section{b. Space and Distance}

In the first meeting the researcher did observation at SMP Negeri 2 Robatal Sampang the teacher ask a student to come forward to write their answer, when the students were writing his answer on black board, the teacher was walking between a students. This is one of step the teacher used space and distance in the classroom to find out the students is doing and who do not do their tasks. To others example of space and distance.

In the second meeting the researcher did observation at SMP Negeri 2 Robatal Sampang. When the teacher come to the classroom before the lesson started, he gave instructions to all of students in order to students clean the floor, after that, the teacher called one groups presentation, while the students was presenting the teacher moves place and he sit between a student's, this is the second steps the teacher used space and distance in teaching learning process to do control to the students in order to students to do not noisy and listen presentation of their friends.

In the second meeting the researcher did observation at SMP Negeri 2 Robatal Sampang, when the teacher in the classroom used space and distance when he explains their material to the students. He was standing in front of students, this space and distance used by the teacher in giving explanations to the student how to present the product, it is steps the teacher to give stimulate the students so that students are motivated to present their products better than before .

\section{c. Touching}

The teacher used nonverbal communication in teaching learning process especially touching. Touching used the teacher in the classroom, he touches a student because the students doesn't want to presentation so that the teacher stands up beside students, he touches their solder of students, its means that the student want to come forward. 


\section{d. Chronemics}

The teacher used nonverbal in teaching learning process especially chronemics. Choronemics used the teacher in giving the material to the students, such as the teacher gives the time to the students for five minutes to prepare their products that would be presentation.

The Teachers' Nonverbal Communication Effect on The Classroom Atmosphere at SMP Negeri 2 Robatal Sampang.

Nonverbal used the teacher at SMP Negeri 2 Robatal Sampang have some effect, helping students understanding and accompanying to verbal message are the effect of on verbal communication.

\section{a. Helping Students Understanding}

$\mathrm{R}$ : What is your name?

$\mathrm{S}$ : Syarifuddin

$\mathrm{R}$ : Where do you come from?

S : Robatal

$\mathrm{R}$ : It nonverbal that used by the teacher make you understand the lesson giving the teacher? Mention what is profit. $S$ : More understanding the lesson that giving by the teacher.
$\mathrm{R}$ : Where are you understand, when the teacher only uses verbal or verbal that accompanying with nonverbal?

S : More understand using verbal that accompanying with nonverbal when the teacher is teaching use nonverbal the material giving the teacher more easily understand.

Syarifudin is a student from Robatal, he is being school at SMP Negeri 2 Robatal Sampang. Syarifudin stride their nonverbal communication that used by the teacher make students understand the lesson given by the teacher, Syarifudin's had more understand the material that explained the teacher when he used nonverbal in teaching learning process. It's easier to the students to get the point of teacher explains. The following is another quotation of Moh.Anwari.

$\mathrm{R}$ : What is your name?

S : Moh. Anwari

$\mathrm{R}$ : Where do you come from?

S : Lepelle

$\mathrm{R}$ : It nonverbal that used by the teacher make you understand the lesson giving the teacher? Mention what is profit.

S : More understanding the lesson that giving by the teacher. 
$\mathrm{R}$ : Where are you understand, when the teacher only uses verbal or verbal that accompanying with nonverbal?

S : More understand using verbal that accompanying with nonverbal the material giving the teacher more easily understand.

Moh. Anwari is a student from Lepelle of Sampang, he was still study at SMP Negeri 2 Robatal sampan. He also had the same opinion to him about nonverbal communication that used by the teacher. It made students understand the lesson giving by the teacher, Moh. Anwari said, their when the teacher used nonverbal in teaching learning process, he more understand the material. It can help the students easier to students to receive the material that's explains by the teacher. The following is another quotation of Nita.

$\mathrm{R} \quad$ : What is your name?
$\mathrm{S} \quad$ : Nita
$\mathrm{R}:$ Where do you come
from?
$\mathrm{S} \quad$ : Robatal
$\mathrm{R} \quad$ : It nonverbal that used
by the teacher make you
understand the lesson
giving the teacher? Mention
what is profit.
S : More understanding the lesson that giving by the teacher.

R : Where are you understand, when the teacher only uses verbal or verbal that accompanying with nonverbal?

S : More understand using verbal that accompanying with nonverbal when the teacher is teaching use nonverbal the material giving the teacher more easily understand.

Nita is one of students had black skin that come from Robatal of Sampang. She studied at SMP Negeri 2 Robatal sampan for two years. When the researcher asks to her nonverbal used the teacher made all of students understand to the teacher's explanation. Nita given argumentation nonverbal that used the teacher in giving material he has ability to pervade the lesson that given by the teacher.

\section{b. Accompanying to Verbal Message}

$$
\begin{aligned}
& \mathrm{R}: \text { What is your name? } \\
& \mathrm{S} \quad \text { : Syarifuddin } \\
& \mathrm{R}: \text { Where do you come } \\
& \text { from? } \\
& \mathrm{S} \quad \text { : Robatal } \\
& \mathrm{R} \quad \text { : It nonverbal that used } \\
& \text { by the teacher make you }
\end{aligned}
$$


understand the lesson

giving the teacher? Mention

what is profit.

S : More understanding

the lesson that giving by the teacher.

R : Where are you

understand, when the teacher only uses verbal or verbal that accompanying with nonverbal?

S : $\quad$ More understand using verbal that accompanying with nonverbal when the teacher is teaching use nonverbal the material giving the teacher more easily understand.

When the researcher give question to Syarifudin which one is better than when teacher explains used verbal or accompanied with nonverbal. Syarifuddin has opinion more understand by using verbal that accompanying with nonverbal because while the teacher teaches used verbal that accompanying with nonverbal in teaching learning process. The students understand of the teacher explain the teacher in giving the lesson in the classroom, and the students to know the mean of nonverbal used the teacher in teaching leaning process. the following is another quotation of Moh. Anwari.
$\mathrm{R}$ : What is your name?
S : Moh.Anwari.
$\mathrm{R}$ : Where do you come from?
S : Lepelle.
R : It nonverbal that used
by the teacher make you
understand the lesson
giving the teacher? Mention what is profit.

S : More understanding the lesson that giving by the teacher.

R : Where are you understand, when the teacher only uses verbal or verbal that accompanying with nonverbal?

S : More understand using verbal that accompanying with nonverbal when the teacher is teaching use nonverbal the material giving the teacher more easily understand.

Moh. Anwari also had given the same opinion about verbal that accompanying with nonverbal, Moh. Anwari had opinion nonverbal used the teacher in teaching learning process, it make the students get the points of his explanation and the used of verbal that accompanying nonverbal in teaching learning process the teacher fell more 
easier to learn English. The following is another quotation of Nita.

$$
\begin{array}{ll}
\mathrm{R} & : \text { What is your name? } \\
\mathrm{S} & : \text { Nita } \\
\mathrm{R} & : \text { Where do you come }
\end{array}
$$$$
\text { from? }
$$$$
\text { S : Robatal. }
$$$$
\mathrm{R} \quad \text { : It nonverbal that used }
$$$$
\text { by the teacher make you }
$$$$
\text { understand the lesson }
$$$$
\text { giving the teacher? Mention }
$$
what is profit.

S : More understanding the lesson that giving by the teacher.

R : Where are you understand, when the teacher only uses verbal or verbal

that accompanying with nonverbal?

S : $\quad$ More understand using verbal that accompanying with nonverbal in the used nonverbal in teaching learning easier understand.

While the researcher given interview to Nita about nonverbal communication that accompanying with verbal message, Nita gave argumentation about nonverbal she had more understand the lesson that give by the teacher. The understanding is while the teacher used nonverbal that combination with verbal message such as the teacher up his hand to explains the material to stimulate knowledge the students.

\section{CONCLUSION AND SUGGESTION}

\section{Conclusion}

From the explanation in finding and discussion, it can be formulated some conclusion. The teacher at SMP Negeri 2 Robatal Sampang used nonverbal those are hands, space \& distance, touching, Chronemics. Hands is nonverbal the most used by the teacher in teaching learning process, The manner of the used hands in teaching learning process he ups his hands to asks a students to come forward. Space \& distance is the second nonverbal that's more often than touching in teaching learning process after hands. It used the teacher to explain his material in the used space and distance the teacher stands up in front of students to explain his material. Touching is nonverbal used the teacher in teaching learning process, touching used the teacher to communication with a student's while the teacher asks a students to come forward if the students didn't want to come forward the teacher 
stand up beside a students and he touches their body, chronemics was rarely used by the teacher in the classroom, chronemics used the teacher while he gives task to the students he gives limed the time to the students to prepare the material that would be presentation.

The effect of nonverbal communication used by the teacher at SMP Negeri 2 Robatal Sampang were helping students understanding and accompanying to verbal message helping students understanding more easier to students to receive the material that's explains by the teacher. Accompanying to verbal message is a student's more easily understand to get the point of teacher explanations in teaching learning process.

\section{Suggestion}

\section{a. For English Teacher}

The teacher should used all of the kinds of nonverbal communication in teaching learning process, not only used nonverbal that understand by the teacher but also used nonverbal have variation so that the teacher more the best to get the material that given.

\section{b. For the Students}

The Students should understand about teachers' nonverbal communication in order that while the teachers ask to do something by using his hands the students can understand the means of the teacher, the students must prepare more material that have been given by the teacher in order that while the teacher call the students to presentation you ready to presented.

\section{c. For the Other Researchers}

This research focused on nonverbal communication, it will be better for the next research to study the nonverbal communication of student's disabilities, deaf people or mute people, before you want to research nonverbal of students' disabilities you must prepare reference related to the material.

\section{REFERENCES}

Barker, Alan. 2006. Improve Your Communication Skills. Second Edition. London and Philadelphia: United Kingdom.

Birjandi, P \& Nushi, M. 2010. Nonverbal Communication in Models of Communicative Competence and 12 Teachers' 
rating. Journal of English

Studies. Islamic Azad

University, Science \& Reseacrh

Branch. Vol 14 No. 3-22.

Creswell, J.W.2009. Reseacrh Design

Qualitative, Quantitave, and

Mixed Methods Approached.

Forth Edition. Sage

Publications. Inc: United States

of America.

DeVito, J. A., 2002. Human

Communication. Allyn \&Bacon, ich Boston.

Hans, A. \& Hans, E. 2015 Aspects of Nonverbal Communication. IOSR Journal of Humanities and Social Science. Assistant Professor in English University of Damman Kingdom of Saudi Arabia. Feb. 2015. Vol. 20 No.1.

Lunenburg, F.C.2010. The Hidden Power of Nonverbal
Communication in the Workplace.International Journal of Scholarly Academic Intellectual Diversity. Sam Houston State University. Vol.12 No. 1. 2010.

Merriam, Sharan. B. 2009. Qualitative Research, a guide to design and Implementation revised and expanded from qualitative research and case study application in education. John Wiley \& Sons. Inc: United States of America.

Miller, Patrick. W. 1988. Nonverbal Communication. Third edition. National Education Association of the United States.

Negi. J.S. 2009. The Role of Teachers' non-verbal communication in ELT Classroom. Journal of NELT. December 2009. Vol. 14 No.1-2. 